\title{
\#HOWTOPPA: AN EXAMINATION OF THE REGULATORY AND COMMERCIAL CHALLENGES AND OPPORTUNITIES Arising in the Context of Private Power Purchase AGREEMENTS FOR RENEWABLE ENERGY
}

\author{
Simon Baines, Shaun Wrubell, Jessica Kennedy, \\ COURTNEY BOHN, AND CASSIE RICHARDS*
}

\begin{abstract}
In recent years, private companies in the United States have increasingly entered into power purchase agreements (PPAs) to procure renewable power from project developers. However, despite favourable market and regulatory regimes for the use of PPAs in Alberta, renewable energy procurement has largely remained the purview of government.
\end{abstract}

To facilitate the increased use of private PPAs in Canada, this article seeks to provide potential renewable energy project developers and customers with a better understanding of how these agreements operate. The authors "demystify" PPAs by reviewing the regulatory structures for PPAs in Alberta, analyzing the factors that might motivate parties to enter into a PPA, and discussing the key contractual terms common to most PPAs.

\section{TABLE OF CONTENTS}

I. INTRODUCTION . . . . . . . . . . . . . . . . . . . . . . . . . . . . . . . . . . . . . . 390

II. WHAT IS A PPA? . . . . . . . . . . . . . . . . . . . . . . 390

III. Growth of the Private PPA In the United States . . . . . . . . . . 391

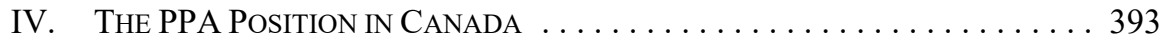

V. Alberta Regulatory Regime . . . . . . . . . . . . . . . . . . . . . . 395

VI. WHY ENTER INTO A PPA? . . . . . . . . . . . . . . . . . . 398

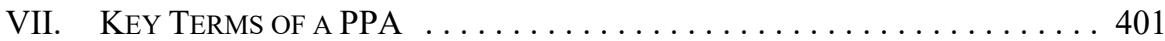

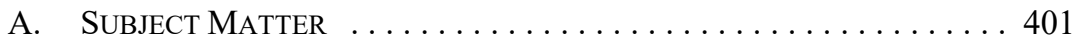

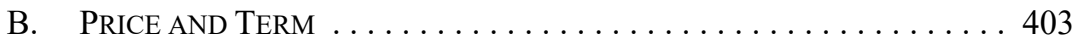

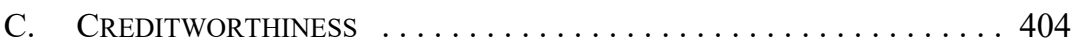

D. Availability AND CURTAILMENT Risk . . . . . . . . . . . 406

E. Change of LaW ....................... 407

VIII. CONCLUSION ........................ 410

Shaun Wrubell is the Vice President, General Counsel, and Corporate Secretary at BluEarth Renewables, a leading, independent power producer that acquires, develops, builds, owns, and operates wind, hydro, and solar facilities across North America. Shaun manages the company's overall legal function and assists with corporate governance, acquisitions, partnership agreements, market expansion, and risk management. Simon Baines is a Partner at Osler, Hoskin \& Harcourt LLP specializing in corporate and commercial matters relating to the natural resource and renewable energy industries. Jessica Kennedy and Cassie Richards are Associates at Osler, Hoskin \& Harcourt LLP specializing in regulatory matters applicable to power producers, resource developers, and industrial facilities. Courtney Bohn is an Associate at Blake, Cassels \& Graydon LLP specializing in corporate finance and securities matters. 


\section{INTRODUCTION}

In recent years there has been a significant increase in the amount of renewable power procured in the United States under corporate or private power purchase agreements (or PPAs). Despite an equally dramatic increase in the number of renewable energy projects planned for development in western Canada over the past few years, we have not seen a corresponding growth or development in the market for private PPAs. Renewable energy procurement has largely remained the purview of government and other public institutions. However, recent public procurement processes in Alberta and Saskatchewan have been significantly oversubscribed, with far more projects proposed for development than governments are willing to buy. ${ }^{1}$ In order for those projects that are unsuccessful in securing a government contract to proceed, a private offtaker through the use of a PPA may well be required.

In this article we review the growth in this industry in the US and then consider how Canadian renewable energy project developers and customers could potentially follow suit. We specifically focus on the Alberta market as both generation and retail are deregulated. Additionally, while there may be some market for financial PPAs in other provinces, the primary interest has been in Alberta. We review the regulatory structures that facilitate private PPAs and then assess certain factors that can motivate both generators and potential customers to enter into a PPA. Finally, we examine some of the common terms of a PPA that are designed to manage and allocate risks between the parties. Our objective is to provide potential developers and customers with a better understanding of how a private PPA functions in the hope that better understanding will facilitate transactions in and help to grow this industry.

\section{WHAT IS A PPA?}

As a starting point, it is worth spending a little time discussing exactly what a PPA is in the context of purchase arrangements between private parties for renewable energy. A PPA is a relatively long-term contract pursuant to which a customer notionally buys electricity directly from a generator. A PPA might also include the purchase of renewable attributes or capacity market products, depending on the desires of the parties.

In Alberta, a PPA for renewable energy will be structured as either a financial PPA or what is sometimes referred to as a "physical" PPA. A financial PPA typically operates as a contract for differences (CFD). Despite the term "power purchase agreement," under a financial PPA there is no physical exchange of electricity between the generator and the customer. The generator delivers all electricity that is notionally the subject of the PPA to the power pool, ${ }^{2}$ and the customer procures electricity from the power pool in the same way as it would absent a PPA. In addition, for all electricity delivered by the generator to the

\footnotetext{
The public procurement processes in Alberta and Saskatchewan are further discussed in Part IV, below. "Power pool' as defined in the Act means the scheme operated by the ISO for (i) exchanges of electric energy, and (ii) financial settlement for the exchange of electric energy" (see Alberta Energy System Operator, "Consolidated Authoritative Document Glossary" (AESO, 2019) at 27, online: <aeso.ca/ assets/Uploads/Consolidated-Authoritative-Document-Glossary-June-1-2019-.pdf> [AESO, "Glossary"]).
} 
power pool, the generator will receive the pool price, ${ }^{3}$ and the customer will pay the pool price for all electricity obtained from the power pool.

The purpose of a financial PPA then is to calculate the difference between the settlement price specified in the PPA and the pool price for each settlement interval ${ }^{4}$ during the term of the PPA - hence the term "contract for differences." For any settlement interval where the settlement price is higher than the pool price, the customer will be required to pay the difference to the generator, and for any settlement interval where the settlement price is lower than the pool price, the generator will be required to reimburse the difference to the customer. The effect of this financial settlement is that the generator will always receive, and the customer will always pay, the settlement price for all of the electricity that is subject to the PPA.

With respect to a physical PPA, notwithstanding the term "physical," there is also no direct delivery of electricity by a generator to a customer. ${ }^{5}$ As with a financial PPA, the generator delivers all electricity that is notionally the subject of the PPA to the power pool, and the customer procures electricity from the power pool in the same way as it would absent a PPA. However, the manner in which the generator sells and the customer purchases electricity from the power pool is different. Under a physical PPA, the generator and customer register a net settlement instruction (NSI) (as discussed further below) with the Alberta Electric System Operator (AESO).

Pursuant to the NSI, the AESO then subtracts the quantity of electricity specified in the NSI from the metered quantity of electricity delivered by the generator to the power pool and procured by the customer from the power pool. Effectively, the AESO nets out the quantity of electricity specified in the NSI so that the generator is not paid by the power pool for that quantity and the customer is not charged by the power pool for that quantity. The generator and customer then settle as between themselves for the quantity of electricity specified in the NSI at the settlement price specified in the PPA.

\section{Growth of the Private PPA IN THE UNITED STATES}

The above discussion provides the necessary framework for considering the growth of PPAs in the US. Over the past few years, major US corporations, educational institutions, and cities have entered into PPAs across the country. This trend is being referred to as "non-

$3 \quad$ Ibid: "'Pool price' as defined in the Act means the price for each hour, in $\$ / \mathrm{MWh}$, established and reported by the ISO, in accordance with the ISO rules, for electric energy exchanged through the power pool."

$4 \quad$ Ibid at 32: “'Settlement interval' means a period beginning on the hour and ending sixty (60) minutes later and is the time increment for which (i) the ISO financially settles energy amounts, and (ii) the load settlement system calculates distinct load estimates."

5 The only situation where a generator would be directly delivering the actual electricity generated by the generation project in question would be if the generation project is co-located at the same site and is directly and physically connected to the load facility. Such a co-located facility is often referred to as a behind-the-fence or behind-the-meter project. Such projects are less common than more traditional non-co-located renewable energy projects and as such are beyond the scope of the discussion in this article. 


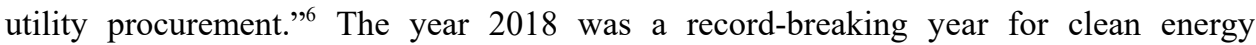
procurement globally. ${ }^{7}$ Purchasing clean energy through PPAs is becoming more attainable, particularly with corporations free to get creative with their PPA structures. Bloomberg New Energy Finance (BloombergNEF) found in its 1H 2019 Corporate Energy Market Outlook that in 2018, approximately $13.4 \mathrm{GW}$ of renewable energy contracts were signed by 121 corporations in 21 countries around the world. Further, since 2008, corporations have contracted for over $32 \mathrm{GW}$ of renewable power, with 40 percent of such activity occurring in 2018. Over 60 percent of the 2018 activity occurred in the US, where corporations signed PPAs for $8.5 \mathrm{GW}$ of renewable energy, which amounted to nearly triple the amount recorded in 2017.8

Market observers have commented that corporations and institutions traditionally received power from local utilities but have started to think about "actively shaping" their power purchases through direct procurement. ${ }^{9}$ Both corporate and institutional carbon reduction goals ${ }^{10}$ and the less expensive costs of purchasing renewable energy have played a part. Further, corporate and institutional non-utility buyers have discovered that the PPA model works well for purchasing renewable energy, because it allows buyers to combine to purchase power at a certain price for a given time from a given project. This allows corporations to avoid high upfront investment costs and access to better opportunities than if they pursued the opportunity alone. ${ }^{11}$

In addition to larger volume PPAs being signed, another trend is occurring in the US where smaller corporate entities are entering the market. In aggregate, the 34 smaller new corporate entities signing PPAs identified by BloombergNEF amounted to 31 percent of the total activity in the US. ${ }^{12}$ Where smaller corporations were once unable to take advantage of PPAs, which required long terms and high-volume commitments, these entities are able to pool their power needs and each claim smaller amounts of the capacity. Additionally, these smaller participants are often partnering with an "anchor tenant" - a larger and more experienced purchaser with a strong balance sheet, bargaining power, and accounting and legal experience. ${ }^{13} \mathrm{We}$ expect this trend to continue in 2019 . Industry observers are noting that making projects "bankable" requires at least part of the project to be hedged. One option is to have the utility provide a floor price, and another is to have a larger corporation offer cover through a PPA. ${ }^{14}$

Sara Hastings-Simon et al, "Perfect Timing for Renewables: Why the Time Is Right for Alberta to Lead in Non-Utility Procurement of Renewable Energy" (2 March 2018), online (blog): Pembina Institute $<$ pembina.org/blog/perfect-timing-renewables $>$.

7

BloombergNEF, "Corporate Clean Energy Buying Surged to New Record in 2018" (28 January 2019), online (blog): <about.bnef.com/blog/corporate-clean-energy-buying-surged-new-record-2018/> [BloombergNEF, “Clean Energy Buying”].

8 Ibid.

9 CanWEA, "Susanne Fratzscher on the Future of Corporate Purchase Agreements in Canada" (October 2018), online: <windenergyevent.ca/news/susanne-fratzscher-on-the-future-of-corporate-purchaseagreements-in-canada/> [CanWEA, "Susanne Fratzscher"].

10 For example, all Apple facilities are currently powered by renewable electricity, and Apple hopes to transition its suppliers to 100 percent renewable electricity: Apple, "Environmental Responsibility Report"(Apple,2019) at 3, online:<apple.com/environment/pdf/Apple_Environmental_Responsibility Report 2019.pdf>

CanWEĀ, "Susanne Fratzscher," supra note 9.

BloombergNEF, "Clean Energy Buying," supra note 7.

Ibid.

Angus McCrone, "Big Oil, Utilities Seen Covering Risks for Wind, Solar: Q\&A" (27 February 2019), online (blog): < about.bnef.com/blog/big-oil-utilities-seen-covering-risks-wind-solar-qa/>. 
Large corporations have been driving the PPA boom in the US over the past couple of years, with popular technology companies heavily involved and taking advantage of the low power rates to power their operations while also meeting sustainability goals. Unlike in Canada, where parties to most PPAs are renewable energy-focused companies, in the US, PPAs appeal to everyone from Google to Apple to Target. Wind power PPAs in particular have become increasingly popular for these organizations, with approximately 75 percent of power contracted through PPAs in the 4th quarter of 2015 purchased by non-utility companies including Procter \& Gamble and General Motors. ${ }^{15}$ Technology and consumer goods are leading the charge with their desire to appeal to their customers on an environmentally friendly platform. Google, for example, intends to become a zero-carbon footprint company and has even released carbon heat map tools designed to allow users to see where they are making progress and where they still have work to do. ${ }^{16}$

Technology companies are not the only ones in the mix in the US. In 2018, Exxon became the first major oil company to sign a renewable power PPA to purchase power for its own operations at the Permian oil field in Texas. ${ }^{17}$ It purchased approximately $250 \mathrm{MW}$ of solar and $250 \mathrm{MW}$ of wind power through two separate PPAs with Danish firm Ørsted as counterparty. ${ }^{18}$ The $250 \mathrm{MW}$ tranche of solar capacity will come from the $350 \mathrm{MW}$ Permian Solar project, which is scheduled for completion in Q2 of 2021. The PPA will have a 12-year term, shorter than many PPAs of the past.

\section{The PPA Position in Canada}

While publicly available information on PPAs in the US is plentiful, Canada lags in both its participation in private PPAs and its curation of information on PPA arrangements. To date, most of Canada's focus has been on government-run competitive bid programs designed to encourage participation in renewable energy generation. Alberta operates its main bid process through the Renewable Energy Program (REP), with the AESO implementing and administering the program. The results of the first round of competitions were announced on 13 December 2017 with four wind projects selected to deliver $600 \mathrm{MW}$ of energy. The weighted average price of the power under the agreements was historically low at $\$ 37$ per MWh or 3.7 cents per kilowatt-hour $(\mathrm{kWh})$, and the range of winning prices varied between $\$ 30.90$ and $\$ 43.30$ per $\mathrm{MWh}$.

David Labrador, "P\&G, GM and Google Take Flight on Wind Power," GreenBiz (25 February 2016), online: <greenbiz.com/article/pg-gm-and-google-take-flight-wind-power>.

Heather Clancy, "3 Takeaways from Google's Search for 'Carbon-Free' Energy,” GreenBiz (19 October 2018), online: <greenbiz.com/article/3-takeaways-googles-search-carbon-free-energy>.

BloombergNEF, "Clean Energy Buying," supra note 7.

John Parnell, “ExxonMobil Signs 250MW Texan Solar PPA,” PV-Tech (29 November 2018), online: $<$ pv-tech.org/news/exxonmobil-signs-250mw-texan-solar-ppa $>$. 
On 17 December 2018, the results of the second and third rounds of competitive bidding were announced. Round 2 delivered $363 \mathrm{MW}$ of wind power at a weighted average bid price of $\$ 38.69 / \mathrm{MWh}$, while Round 3 resulted in $400 \mathrm{MW}$ of wind generation at a weighted average bid price of $\$ 40.14 / \mathrm{MWh}$. The winners are set out in the table below: ${ }^{19}$

\begin{tabular}{|c|l|l|c|}
\hline Round & \multicolumn{1}{|c|}{ Project Owner } & \multicolumn{1}{|c|}{ Project } & MW \\
\hline 1 & EDP Renewables Canada Ltd. & Sharp Hills Wind Farm near Oyen & 248.4 \\
\hline 1 & Enel Green Power Canada, Inc. & Riverview Wind Farm near Pincher Creek & 115 \\
\hline 1 & Enel Green Power Canada, Inc. & $\begin{array}{l}\text { Phase 2 of Castle Rock Ridge Wind } \\
\text { Power Plant near Pincher Creek }\end{array}$ & 30.6 \\
\hline 1 & Capital Power Corporation & Whitla Wind near Medicine Hat & 201.6 \\
\hline 2 & EDF Renewables Canada Inc. & $\begin{array}{l}\text { Cypress Wind Power Project near } \\
\text { Medicine Hat }\end{array}$ & 201.6 \\
\hline 2 & Potentia Renewables Inc. & Stirling Wind Project near Lethbridge & 113 \\
\hline 2 & Capstone Infrastructure Corporation & Buffalo Atlee Wind Farm 1 near Brooks & 17.25 \\
\hline 2 & Capstone Infrastructure Corporation & Buffalo Atlee Wind Farm 2 near Brooks & 13.8 \\
\hline 2 & Capstone Infrastructure Corporation & Buffalo Atlee Wind Farm 3 near Brooks & 17.25 \\
\hline 3 & TransAlta Corporation & Windrise Wind near Pincher Creek & 207 \\
\hline 3 & Potentia Renewables Inc. & Jenner Wind Power Project near Brooks & 122.4 \\
\hline 3 & Potentia Renewables Inc. & Jenner Wind Power Project 2 near Brooks & 71.4 \\
\hline
\end{tabular}

In addition to the REP, the Alberta government, through the Minister of Infrastructure, initiated a solar-specific procurement in October $2018 .{ }^{20}$ This procurement sought to source approximately 55 percent of the government's annual electricity requirements. ${ }^{21}$ In February 2019, it was announced that Canadian Solar Inc. had "won three solar power contracts with Alberta's Ministry of Infrastructure" for a total of 94 MW of solar power, with an average contracted PPA price of $\$ 48.05 / \mathrm{MWh}^{22}$

Aside from the REP competitive bid process and the solar-specific procurement, little information is available about other PPAs being entered into in Alberta and across Canada, ${ }^{23}$

Alberta Electric System Operator, "REP Results," online: <aeso.ca/market/renewable-electricityprogram/rep-results/> [AESO, "REP Results"].

20 JWN Energy, "Alberta Looking for Solar to Power More than Half of Government Needs," JWN (3 October 2018), online: <jwnenergy.com/article/2018/10/alberta-looking-solar-power-more-half-govern ment-needs/>.

21 Ibid.

22 Canadian Solar Inc, News Release, "Canadian Solar Won 94 MWp of Subsidy-Free Electricity Contracts in Alberta's Public Power Auction" (15 February 2019), online: <prnewswire.com/news-releases/ canadian-solar-won-94-mwp-of-subsidy-free-electricity-contracts-in-albertas-public-power-auction300796671.html>.

23 Saskatchewan has also engaged in procurement processes. For example, in order to meet its goal of $60 \mathrm{MW}$ of solar power by 2021, SaskPower has sought requests for proposals for utility-scale solar projects (see "Second 10 MW Solar Project" (2019), online: <saskpower.com/Our-PowerFuture/Infrastructure-Projects/Construction-Projects/Current-Projects/Second-10MW-Solar-Project>). Saturn Power was the winner of Saskatchewan's first utility-scale solar power project. SaskPower and Saturn Power signed a 20-year power purchase agreement for $10 \mathrm{MW}$ of solar power (see SaskPower, News Release, "Saturn Power to Build Province's First Utility-Scale Solar Project" (19 June 2018), online: <saskpower.com/ about-us/media-information/news-releases/Saturn-Power-to-buildprovinces-first-utility-scale-solar-project>). One company that has been active across Canada, particularly with wind projects on the coasts, is ENGIE. According to its portfolio of projects, ENGIE is party to three ongoing 20-year PPAs with (i) the city of Summerside, PEI for 9 MW of power from ENGIE's Norway Wind Park, (ii) New Brunswick Power Group for up to 99 MW of power from 
particularly in terms of private PPAs between corporations. However, we understand that corporations are increasingly looking to procure renewable energy in Alberta. The Business Renewables Centre is one organization that is providing support to corporations and project developers to accelerate the uptake of renewable energy. ${ }^{24}$ Through the Business Renewables Centre, energy project developers have access to PPA templates and training. ${ }^{25}$ One approach in the US that may further facilitate the growth of PPAs in Alberta is the combining of multiple entities to secure PPAs where they might not be able to do so otherwise.

Another trend appears to be participation in US markets by US subsidiaries of Canadian corporations, which indicates an interest and willingness to participate in renewable energy PPAs but potentially a lack of appropriate market conditions within Canada. For example, Canadian Solar Inc. announced that its wholly owned US subsidiary, Recurrent Energy, LLC, had signed a 25-year PPA for the $63 \mathrm{MWac} / 88 \mathrm{MWp}$ Stanford Solar Generating Station \#2 located in California. The agreement was entered into with Stanford University, which has been working towards gathering enough clean energy to equal the university's annual electricity consumption. ${ }^{26}$

The slow growth of corporate PPAs in Canada has not gone unnoticed, and efforts have been made to create easier options for Canadian companies to engage in shorter-term PPAs, particularly with foreign emerging markets. Canadian Commercial Corporation's (CCC) new PPA offering attempts to appeal to entities wary of changing political winds. The CCC provides this offering by signing the PPA with the foreign buyer and a second "domestic contract" with the Canadian company leading the project. This brings the Government of Canada in on the deal, offering increased bargaining power and the ability to enforce performance of the agreement. ${ }^{27}$

\section{Alberta Regulatory Regime}

Not every jurisdiction is amenable to PPAs. Location and regulation will determine whether a PPA can be entered into and the type of PPA that can be executed. In the US, retail markets are determined by the state government and are either traditionally regulated or competitive. In a regulated retail market, customers are not able to choose who generates their power and must buy from their local utility. ${ }^{28}$ This has made it difficult to develop large green power projects in states that are traditionally regulated. To enter into a physical PPA in the US, the customer "must be in a competitive retail market and the project must be in

ENGIE's Caribou Wind Park, and (iii) BC Hydro for 99 MW from ENGIE's Cape Scott wind farm on Vancouver Island (see "Discover ENGIE Activities in Canada," online: <engie.com/en/group/ourinternational-presence/canada/ $>$ ).

24 See Business Renewables Centre, "What We Do," online: $<$ businessrenewables.ca/about $/>$.

25 See Business Renewables Centre, "Member Benefits," online: <businessrenewables.ca/memberbenefits>.

26 Canadian Solar Inc, News Release, "Canadian Solar Subsidiary Recurrent Energy Signs Power Purchase Agreement with a Leading Silicon Valley University" (3 December 2018), online: <prnewswire.com/ news-releases/canadian-solar-subsidiary-recurrent-energy-signs-power-purchase-agreement-with-aleading-silicon-valley-university-300758945.html>.

27 Canadian Commercial Corporation, "Lower-Risk Power Purchase Agreements Help Canadian Cleantech Exporters Expand into New Markets" (16 January 2019), online: <info.ccc.ca/insights-for-exporters/ lower-risk-power-purchase-agreements-help-canadian-cleantech-exporters-expand-into-new-markets $>$.

28 See United States Environmental Protection Agency, "US Electricity Grid \& Markets" (2017), online: $<$ www.epa.gov/greenpower/us-electricity-grid-markets>. 
a competitive wholesale market that is interconnected with the [customer's independent system operator]." ${ }^{29}$ This contrasts with a virtual PPA, where the customer "can be anywhere in the U.S." but "the project must be in a competitive wholesale market." 30

As in the US, PPAs are only available in some Canadian jurisdictions. Alberta has been described by the Pembina Institute as an ideal place to lead the practice of non-utility procurement through practices such as PPAs due to its deregulated market, renewable energy target of 30 percent by 2030, and the numerous renewable energy projects planned and in development. ${ }^{31}$ In contrast, a private PPA is not possible in some provinces. For instance, Manitoba and Saskatchewan prohibit the retail supply of power from any persons other than Manitoba Hydro or SaskPower, respectively. ${ }^{32}$

As Alberta is a deregulated market, it allows generators to enter into contracts directly with other private parties, providing an opportunity for participants to enter into PPAs. This is in contrast to many Canadian jurisdictions that traditionally have had province-wide, vertically integrated utilities, meaning that the utility owns all levels of the supply chain: generation, transmission, and distribution. ${ }^{33}$ In 1996, the Electric Utilities Act (EUA) came into effect and initiated power deregulation in Alberta. ${ }^{34}$ The EUA also introduced the concept of a power pool structure, which requires that all power entering or leaving the Alberta Interconnected Electrical System (AIES) be "the subject of transactions through a single power pool." 35

The current EUA continues to require that all electric energy entering or leaving the AIES in Alberta be exchanged through the power pool. ${ }^{36}$ The power pool is the scheme operated by the Independent System Operator (ISO), which in Alberta is the AESO, for the exchange and financial settlement of electric energy ${ }^{37}$ In Alberta, the ISO has the obligation to operate the power pool in a manner that promotes the fair, efficient, and openly competitive exchange of electric energy and to carry out the financial settlement for all electric energy exchanged through the power pool at the pool price. ${ }^{38}$ The pool price is established by the ISO for each settlement interval. ${ }^{39}$ The method for determining the pool price is discussed below.

As the settlement intervals are one-hour increments, ${ }^{40}$ this means that the pool price is set every hour. Every generating unit with a maximum capacity of five MW or greater must

Ibid.

Ibid.

Hastings-Simon et al, supra note 6.

See Manitoba Hydro Act, RSM 1987, c H190, s 15.2; The Power Corporation Act, RSS 1978, c P-19, s 38 .

Gowling Lafleur Henderson LLP, The Electricity Industry in Canada (Toronto: Thomson Reuters, 2009)

(loose-leaf updated 2019, release 1), ch 6 at 6.1.1.

Ibid, ch 6 at 6.1.7.

Ibid, ch 6 at 6.1.6.

See Electric Utilities Act, SA 2003, c E-5.1, s 18(2) [EUA]. There are some exceptions, however. For example, section 18(2) of the EUA "does not apply to electric energy from small micro-generation entering the interconnected electric system": Micro-Generation Regulation, Alta Reg 27/2008, s 6. EUA, ibid, s 1(1)(mm).

Ibid, ss 17(a), (d).

Ibid, s 18(4)(a).

AESO, "Glossary," supra note 2 at 32 ("“settlement interval' means a period beginning on the hour and ending sixty (60) minutes later"). 
submit an offer to sell electric energy for each settlement interval. ${ }^{41}$ The offer includes a price in dollars, between zero and 999, per megawatt hour (MWh) and the quantity of electricity in megawatts that the generator wishes to sell. ${ }^{42}$ Offers can be submitted as early as seven days before the relevant settlement interval, but must be submitted by noon the day before. ${ }^{43}$ The price of the offer can be changed up to two hours before the settlement interval. After the two-hour mark, no further changes can be made. ${ }^{44}$ Typically, wind generators offer their electric energy at $\$ 0 / \mathrm{MWh}$. It has been suggested that wind generators are willing to offer at $\$ 0 / \mathrm{MWh}$ because they have minimal variable costs and offering at $\$ 0 / \mathrm{MWh}$ ensures that their electricity gets dispatched. ${ }^{45}$ This strategy plays on the fact that the AESO creates a merit order based on the submitted offers. The merit order sorts offers from the lowest-priced to the highest-priced. The AESO's system controllers then dispatch the lowest-priced orders first and move up the merit order until all electricity required to meet demand has been dispatched. $^{46}$

Just because a generator offers $\$ 0 / \mathrm{MWh}$ does not mean they are paid $\$ 0 / \mathrm{MWh}$ for their electricity. The last offer dispatched from the merit order to meet demand sets the system marginal price (SMP). ${ }^{47}$ For example, if offers in the merit order are priced between $\$ 0$ and $\$ 100$ and the last offer dispatched is $\$ 60$, the SMP is $\$ 60$. The SMP is set every minute and is then used in the calculation of the pool price. Every hour, the pool price is calculated by averaging all 60 of these one-minute SMPs. ${ }^{48}$ As noted above, the ISO is responsible for the financial settlement of all electric energy exchanged through the power pool. The payment to the generator is calculated by taking the metered energy for the settlement interval and subtracting any NSI, which is further discussed below, then multiplying this by the pool price. $^{49}$

The NSIs are relevant to the consideration of PPAs in Alberta. Similar to the US, PPAs in Alberta are structured as either a physical or financial PPA. However, as noted above, a physical PPA in Alberta does not involve the direct physical sale of electricity because all electric energy entering or leaving the AIES must be exchanged through the power pool. ${ }^{50}$ Under a financial PPA, the buyer continues to pay and the seller continues to receive the pool price. The parties then calculate the difference between the pool price and the fixed contract price and settle the difference between themselves. The main distinction between a financial and physical PPA in Alberta is the involvement of the ISO. Under a physical arrangement, the parties register an NSI with the ISO. ${ }^{51}$ In conducting its financial settlement, the ISO subtracts the contracted volume from the buyer's and seller's actual metered volumes. By

Alberta Electric System Operator, "ISO Rules" (AESO, 2018), Section 203(1), art 3(1), online: $<$ aeso.ca/rules-standards-and-tariff/iso-rules/complete-set-of-iso-rules/> [AESO, "ISO Rules"]. Ibid, Section 203.1, art 3(3).

Ibid, Section 203.1, art 2(2).

Alberta Electric System Operator, "Guide to Understanding Alberta's Electricity Market," online: $<$ aeso.ca/aeso/training/guide-to-understanding-albertas-electricity-market/> [AESO, "Guide"].

AlbertaPowerLaw, "Selling Electricity for Nothing in Alberta: More Zero Dollar Hours in 2017" (20 September 2017), online: <albertapowermarket.com/2017/09/20/selling-electricity-for-nothing-inalberta-more-zero-dollar-hours-in-2017/>.

AESO, "Guide," supra note 44.

Ibid.

Alberta Electric System Operator, "How is the Pool Price for Electricity Determined?" (AESO, 2018), online: <aeso.ca/download/listedfiles/How-the-Pool-Price-is-Determined-2018.pdf>.

See AESO, "ISO Rules," supra note 41, Section 103.4, art 3(1).

See EUA, supra note 36, s 18(2) and accompanying text.

AESO, "ISO Rules," supra note 41, Section 103.5. 
registering an NSI, the parties do not need to calculate the difference between the contracted and pool price. The parties will settle between themselves for the contracted volumes, and the ISO will charge the buyer the pool price for any volume above the contract amount. If the electricity consumed is less than the NSI volume, the buyer sells the additional volumes to the ISO at the pool price.

\section{WHY ENTER INTO A PPA?}

From a generator's perspective, the reasons for entering into a PPA are obvious and straightforward. A PPA will provide a generator with revenue certainty for the project or projects supplying the electricity that is the subject of the PPA. In the absence of a PPA, a generator's only option is to sell electricity at the prevailing pool price for each settlement interval. In Alberta's deregulated market, this means that the price to be received by the generator for electricity will vary hour by hour, day over day, based on supply and demand factors which will be almost entirely outside the control of the generator. Further, as Alberta's power pool only involves the sale of electricity generated by a project and does not include any of the renewable attributes resulting from the project, a generator is left to try to find a purchaser for these renewable attributes outside of the power pool. This lack of certainty of sufficient revenue can make it exceptionally difficult to secure financing to develop a renewable energy project, as project finance lenders generally want to have a high degree of comfort that the revenue from the project that they will be financing will be capable of satisfying the debt repayment obligations. Consequently, for generators intending to rely on project financing to support the development of a project, a long-term PPA can be a necessary requirement to make a final investment decision to proceed with a project.

From a customer's perspective, the arguments for entering into a PPA may be less obvious, but renewable energy procurement can be attractive for a variety of reasons such as helping to meet environmental regulatory obligations, helping to achieve sustainability or social responsibility goals or targets, branding, competitive pricing, and price certainty. Most Canadian provinces have instituted some form of carbon tax or price on carbon, at least in respect of some elements or portion of their respective economy. ${ }^{52}$ The federal government has decided to impose a national carbon $\operatorname{tax}^{53}$ on those provinces that have not yet

52 British Columbia imposed a carbon tax in 2008; tax rates are based on a price of $\$ 30 /$ tonne of CO2 equivalent emissions. Quebec has had a cap-and-trade system in place since 2013. Nova Scotia has implemented a cap-and-trade system. Prince Edward Island has implemented a two-part plan that includes a carbon price for consumers that is administered by the province and an output-based pricing system for large emitters that is administered by the federal government. Newfoundland has implemented a hybrid approach that came into effect on 1 January 2019. This approach includes performance standards for large industrial facilities and large-scale electricity generation as well as a carbon tax on transportation, building fuels, electricity generation, and other fuels combusted in the province. The Northwest Territories has introduced a carbon tax on fuels that will be effective 1 July 2019 , based on $\$ 20 /$ tonne of greenhouse gas emissions. This amount will increase annually to $\$ 50 /$ tonne. In 2016, the federal government released its planned approach to pricing carbon pollution (see Government of Canada, Pan-Canadian Framework on Clean Growth and Climate Change (Ottawa: Government of Canada, 2016) online: <publications.gc.ca/collections/collection_2017/eccc/En4-2942016-eng.pdf $>$ ). Central to this framework is the requirement for provinces to implement (i) an explicit price-based system (a carbon tax or a carbon levy and performance-based emissions system) or (ii) a cap-and-trade system. See Greenhouse Gas Pollution Pricing Act, SC 2018, c 12. The Act, which implements the federal carbon pollution pricing system, came into effect in June 2018. The Act is composed of two key parts. Part 1, which is administered by the Canada Revenue Agency, applies to 21 types of fuel and combustible waste. Part 2, which is administered by Environment and Climate Change Canada, introduces an output-based pricing system for industrial facilities. Part 1 of the federal system applies in Saskatchewan, Manitoba, Ontario, and New Brunswick as of 1 April 2019, and in 
implemented a price on carbon. ${ }^{54}$ As such, there is a readily discernible price on emissions. If a potential customer's business involves emitting greenhouse gases or other pollutants captured by such environmental legislation, then there will be a compliance cost associated with that business. While reducing emissions from the business is of course one way for such a potential customer to reduce these costs, most carbon pricing schemes also allow for the purchase of renewable energy credits to offset emissions. ${ }^{55}$ The renewable attributes generated by many renewable energy projects may qualify as renewable energy credits. Here in Alberta, such a renewable attribute can be serialized into an "emission offset" under the Carbon Competitiveness Incentive Regulation. ${ }^{56}$ A potential customer looking to acquire emission offsets to reduce its compliance costs associated with the emissions from its business could procure such emission offsets from a generator pursuant to a PPA. Going forward in this article, these renewable attributes or emission offsets will be generally referred to as renewable energy credits (RECs).

Procuring renewable power may also assist a potential customer to achieve sustainability or "green" goals or targets that the customer may have set for its business. Publishing (and more importantly living up to) these types of goals has increasingly become an important element of branding for some businesses. "Power Forward 3.0," a report issued by the World Wildlife Fund and Ceres (among others) in April 2017, found that 48 percent of Fortune 500 companies and 63 percent of Fortune 100 companies have established one or more clean energy targets, representing a 5 percent increase from $2014 .{ }^{57}$ While we have not been able to identify a more current estimate, our expectation is that this number has only continued to grow over the past two years. A significant percentage of some of the largest businesses in the world have established clean energy targets, and many businesses publicly promote the setting and achievement of these targets. As discussed above, a PPA with a renewable power generator provides an opportunity for a potential customer to procure RECs generated by the renewable energy project, which may assist that potential customer in meeting its clean energy targets and promoting its brand.

Further, a PPA may be attractive to a potential customer both in terms of price and price certainty. As with generators, consumers of power in Alberta are exposed to electricity prices that vary hour by hour, day over day. While there are certainly hedging contracts and other financial instruments and strategies that a potential customer might employ to address this

Nunavut and Yukon beginning 1 July 2019. The remaining jurisdictions are not subject to the federal regime as they have implemented their own carbon regimes.

54 In November 2015, Alberta announced the Climate Leadership Plan, which included the implementation of a carbon price across all sectors of \$20/tonne in 2017 and rising to \$30/tonne in 2018. However, recently elected premier Jason Kenney plans to introduce legislation that will end the current carbon tax by 30 May 2019. The government has proposed to replace the current carbon tax with a program targeting large emitters of greenhouse gas. As a result, it is possible that the federal government may seek to impose its federal carbon tax on Alberta.

55 See Greenhouse Gas Emission Control Regulation, BC Reg 250/2015; Carbon Competitiveness Incentive Regulation, Alta Reg 255/2017 [CCIR]; Regulation Respecting a Cap-and-Trade System for Greenhouse Gas Emission Allowances, CQLR c Q-2, r 46.1; Cap-and-Trade Program Regulations, NS Reg 194/2018; Management of Greenhouse Gas Act, SNL 2016, c M-1.001. The federal Greenhouse Gas Pollution Pricing Act, supra note 53, provides that regulations may be made regarding the transfer of surplus credits and the creation of an offset credit system. However, no such regulations are currently in place.

56 CCIR, ibid.

57 World Wildlife Fund et al, "Power Forward 3.0" (2017) at 2, online: <c402277.ssl.cf1.rackcdn. com/publications/1049/files/original/Power_Forward_3.0_-_April_2017_-_Digital_Second_Final.pdf $>$. 
price risk, a long-term PPA is also a viable option. A PPA provides customers with price certainty for the electricity purchased under the PPA for the term of the PPA and may well be an easier solution to implement and manage than other hedging strategies.

Further, the actual price for electricity (and RECs) purchased under a PPA may also be very competitive with the pool price. One recent report shows a continued decline in the cost of generating electricity from utility-scale solar and wind and in certain cases costs have decreased to the point that they are now at or below the marginal cost of conventional generation. ${ }^{58}$ The report indicates that over the past nine years the mean levelized cost of energy for unsubsidized wind projects has declined by 69 percent while the mean levelized cost of energy for unsubsidized utility-scale solar projects has declined by 88 percent over the same period. ${ }^{59}$ Another report in June 2017 from BloombergNEF estimates that the levelized cost of energy from solar projects will decline by 66 percent and the levelized cost of energy from onshore wind projects will drop by 47 percent, in each case between 2017 to $2040 .{ }^{60}$ So, while costs may not continue to drop at the same rate as they have over the past decade, it seems reasonable to expect that there will be continued and material reductions in costs over the next 20 years.

These cost reductions have contributed to record low prices for public procurement of renewable power over the past few years. In December 2017, the first auction under the Renewable Electricity Program in Alberta resulted in what was then the "lowest-ever rate paid for wind energy" in Canada at a weighted average of \$37/MWh. ${ }^{61}$ A competitive procurement process in Saskatchewan in October 2018 resulted in a winning bid of less than \$35/MWh, ${ }^{62}$ and the results of REP2 and REP3 in Alberta were announced in December 2018 with 760 megawatts of capacity procured at an average weighted price of $\$ 39 / \mathrm{MWh}{ }^{63}$ Most recently, in February 2019, Alberta Infrastructure entered into a 20-year agreement to procure approximately $146,000 \mathrm{MWh}$ per year of renewable power generated from three solar projects for an average price of $\$ 48 / \mathrm{MWh}$.

By way of comparison, the average Alberta pool price in 2017 was $\$ 22.19 / \mathrm{MWh}$ (with an on-peak average of $\$ 24.46$ and an off-peak average of $\$ 17.64),{ }^{64}$ and in 2018 it was $\$ 50.35 / \mathrm{MWh}$ (with an on-peak average of $\$ 59.28$ and an off-peak average of $\$ 32.47$ ), ${ }^{65}$ and the rolling 30-day average as of early April 2019 was in the range of \$50/MWh. ${ }^{66}$ Competitive public procurement over the past two years has achieved prices that are materially below the average pool price since 2018 , and some market commentators expect

\footnotetext{
58 Lazard, "Lazard's Levelized Cost of Energy Analysis - Version 12.0” (Lazard, 2018), online: $<$ www.lazard.com/media/450784/lazards-levelized-cost-of-energy-version-120-vfinal.pdf $>$. Ibid at 8 .

BloombergNEF, "New Energy Outlook 2017: Executive Summary" (Bloomberg Finance, 2017) at 2, online: <res4med. org/wp-content/uploads/2017/06/BNEF_NEO2017_ExecutiveSummary.pdf $>$. CanWEA, “Affordable Power,” online: <canwea.ca/wind-facts/affordāble-power/>.

Ibid.

Government of Alberta, News Release, "Wind Projects Create Jobs, Indigenous Partnerships" (17 December 2018), online: <alberta.ca/release.cfm?xID=6225465E583D7-C8A6-0844-D9754D497BA00 D68>.

${ }_{64}$ See Alberta Electric System Operator, “AESO 2017: Annual Market Statistics” (AESO, 2018) at 3, online: <aeso.ca/download/listedfiles/2017-Annual-Market-Stats.pdf>.

See Alberta Electric System Operator, “AESO 2018 Annual Market Statistics Reports” (AESO, 2019) at 3, online: <aeso.ca/download/listedfiles/2018-Annual-Market-Stats-WEB-FINAL.pdf>. See Alberta Electric System Operator, "Pool Price - Historical," online: <ets.aeso.ca>.
} 
the pool price to continue to rise. ${ }^{67}$ Against this backdrop, the competitive pricing and price certainty available through a long-term PPA with a renewable energy project developer may be very attractive to a potential customer.

\section{KEY TERMS OF A PPA}

As with any significant contract intended to endure for more than a decade, a long-term PPA has far too many important provisions to address all of them within the confines of this article. As such, we have focused on the following five areas that in our view are both critically important to the negotiation and formation of a PPA and also more or less unique to the PPA context relative to other long-term commercial arrangements:

(1) What is the subject matter of the PPA? What is actually being bought and sold? Just electricity? RECs as well? Capacity products? This is a fundamental element of any PPA and allows for more options than might at first be expected.

(2) What is the term of the PPA and the price for the products being sold? Again, this question highlights fundamental commercial issues, the resolution of which will necessarily reflect the competing priorities of generator and customer.

(3) How should the creditworthiness of the counterparty to a PPA be assessed and addressed? While a long-term PPA is fundamentally designed to provide price and revenue certainty for the parties, the PPA (and hence that certainty) may only be as good as the credit of the parties.

(4) Who should bear the risk that a generator is constrained from delivering electricity to its customers? The transmission and distribution systems are (generally) beyond the control of either party to a PPA, yet can materially impact the arrangement between the parties.

(5) How will changes in law be addressed? Who will bear the risk that future governmental, legislative, or regulatory changes could materially impact either the cost of providing a product or the value of that product?

Below we address each of these five areas of concern and the terms of a PPA to address them.

\section{A. SubJect Matter}

Not surprisingly, the most fundamental term of a PPA is the subject matter of the agreement. Most PPAs for renewable power will include both energy (that is, the renewable power) and the RECs resulting from the generation of that renewable power at the associated renewable energy project. A PPA is typically expressed in terms of the capacity of electricity that is being procured (for example, the $122 \mathrm{MW}$ procured from the Jenner Wind Power 
Project pursuant to the Renewable Electricity Program Round 3$)^{68}$ but will also often include the associated RECs. This is consistent with the "Indexed Renewable Energy Credit" or "Contract for Difference" mechanism used by the AESO under the Renewable Electricity Program where the AESO procured both a certain capacity of electricity and the associated RECs. ${ }^{69}$

Notwithstanding that most PPAs typically will, there is no requirement for a PPA to include both electricity and RECs. A generator and customer could enter into a PPA solely with respect to electricity. In such a situation, the generator and customer would settle between themselves for any differences between the contract price and the pool price for all applicable settlement intervals during the term (as discussed above). In this case, the customer purchasing just the electricity would not be entitled to make claims about using "green power" since the renewable attributes (or "greenness") associated with that power will be retained by the generator and may be sold to another party. However, if a customer is more concerned with securing long-term power supply at a fixed (or at least known or ascertainable) price and less concerned with the acquisition of RECs (either because such a customer does not require additional RECs to reduce emissions compliance costs or to "green" its image), then the lack of RECs may not be an issue and may actually be attractive to both parties.

Any PPA that only includes electricity as contemplated above will necessarily provide a generator with the opportunity to also enter into a PPA to cover just the sale of RECs (although here the term PPA may be less appropriate as no power will actually - or even notionally - be sold pursuant to such an agreement). Such an agreement would not be all that different from the "Indexed Renewable Energy Credit" arrangement used by the AESO under the Renewable Electricity Program. As all electricity is actually purchased and sold through the power pool, what is left is really just a financial settlement based on contract price relative to pool price in consideration for the transfer of RECs. One could easily envision a PPA (or some other form of contract) that dispenses with the notional sale of electricity and just addresses the sale of RECs based on the same financial settlement methodology - the price of the RECs is determined based on the difference between an agreed contract price and the pool price. Clearly, the prices in question here are in reference to electricity, but no actual electricity would need to be procured for the same result to be achieved. On the other hand, parties could also simply agree on a fixed price for the sale of RECs or attempt to tie the transaction price to an external market value for RECs.

One final element to be considered in connection with a PPA in Alberta is the inclusion or exclusion of any revenues earned through the ancillary services market and any capacity products that the associated renewable energy project may secure through future capacity market auctions. While the final implementation of the capacity market in Alberta is still uncertain, the AESO has indicated that the first capacity market auction is to take place in

68 AESO, "REP Results," supra note 19.

69 Alberta Electric System Operator, “About the Program” (2016), online: <aeso.ca/market/renewableelectricity-program/about-the-program/>. 
2019 in respect of the first capacity obligation period in $2021 .^{70}$ If the capacity market proceeds, then future renewable energy projects may have access to an additional revenue stream that is currently unavailable under the energy-only market currently in place in Alberta. How this revenue stream will (or will not) be addressed or accounted for under a PPA is a commercial matter that should be discussed between a generator and its potential customers.

\section{B. PRICE AND TERM}

Once the fundamental subject matter of an agreement has been determined, the next most critical commercial elements to be agreed upon are (1) the price of the electricity, RECs, ancillary services, and capacity products subject to the PPA, and (2) the term of the arrangement. While ultimately separate terms, these two elements of a PPA are closely connected and in many cases may well be dependent on one another - namely, a party's willingness to agree to a certain price for a product may depend on the term of the arrangement, such as a generator willing to accept a lower price in the context of a longer term, sacrificing potential revenue for longer-term certainty and stability.

In the US, PPAs for renewable power have typically been for a term of at least ten years. ${ }^{71}$ These longer-term agreements are primarily driven by the desire of generators for revenue certainty and security. Particularly where a renewable energy project is going to be project financed (that is, financed on a non-recourse basis where a lender's security will largely be limited to the renewable energy project in question), the lenders providing the financing will want to make sure that the project will have sufficient revenue to satisfy the applicable debt service requirements. As the term of the financing is in all likelihood going to be more than two to three years, a generator needs to secure a longer-term offtake arrangement (for example, a PPA) to support repayment of the debt over that longer period.

In addition to providing long-term revenue certainty and stability for a generator, a PPA can also provide long-term price certainty for a customer. As noted above, many expect the pool price to continue to rise in 2019 and beyond. For a business where electricity is a material part of its operating costs, exposure to rising power prices can be a significant business risk - particularly if the drivers of rising power prices are not strongly correlated with factors that could result in increased revenue for that business. This risk can be managed and mitigated through a long-term PPA, providing a customer with an opportunity to lock in power prices for a prolonged period of time and thereby eliminate the volatility and uncertainty of power prices otherwise present in a deregulated market such as in Alberta.

70 Alberta Electric System Operator, "Capacity Market Transition” (2016), online: <aeso.ca/market/ capacity-market-transition/ $>$. Since the time this article was written and prior to publication, the Alberta Government cancelled the capacity market transition, thereby maintaining the current energy-only market structure. These recent developments highlight that power market structures are vulnerable to regulatory change and PPAs should be drafted to account for revenue streams that may become available over the PPA term.

71 Sara Hastings-Simon et al, "Plugging In: Opportunities to Procure Renewable Energy for Non-Utility Companies and Institutions in Alberta" (Calgary: Pembina Institute \& Rocky Mountain Institute, 2018) at 15, online: <pembina.org/reports/plugging-in-2018.pdf>. 
However, while a longer term does provide an opportunity to achieve certainty and stability, it also introduces the risk that a party may agree to a price that ends up being significantly above or below "market" depending on a party's perspective. The fear of entering into an agreement that could end up being materially off-market for a prolonged period of time can make it harder for potential parties to a PPA to reach agreement. One way to address this additional risk is through indexation or some other form of price adjustment or escalation mechanism. ${ }^{72}$ By providing that the contract price will increase or decrease over time in correlation to a corresponding increase or decrease in a publicly available index or market price (such as the Consumer Price Index (CPI), which is a common choice for such provisions), the risk of a PPA being significantly off-market for a prolonged period can be greatly mitigated.

This indexation approach can be seen (in part) in the draft Renewable Electricity Support Agreement (RESA) published by the AESO ${ }^{73}$ Under article 6.3 of the RESA, the Strike Price (as defined in the RESA) will be partially adjusted based on changes in CPI (and for the purposes of the RESA, CPI is defined as the Consumer Price Index for Alberta, all items). While 80 percent of the Strike Price for any contract year shall remain as the initial price bid under the REP, the remaining 20 percent of the Strike Price will be adjusted based on changes to CPI. As the RESA has a 20-year term, this Strike Price adjustment mechanism (even if only applicable to 20 percent of the Strike Price and therefore 20 percent of the revenue stream of a generator) helps to mitigate the risk of a generator's bid by providing some comfort that the Strike Price will not be completely disconnected from rising prices in the economy generally that could well be reflected in rising pool prices, which in turn could result in the Strike Price under a RESA being significantly off-market.

\section{CREDitWorthinesS}

Both a generator and a potential customer will be concerned with the creditworthiness of the prospective counterparty to a PPA, and the substance (or lack thereof) of a counterparty may well be a factor that is considered in connection with reaching agreement on the price and term of the PPA. From a generator's perspective, a PPA (particularly a long-term PPA) may well be providing the financial support (or at least revenue certainty) necessary for the generator to proceed with the construction of the renewable energy project. This is certainly not unique to the renewable energy industry. In the oil and gas industry, it is quite common for proponents of significant infrastructure or capital projects to seek long-term commitments from customers prior to proceeding. Significant pipeline expansions are generally underpinned by long-term commitments from shippers. New gas processing plants and facilities are typically only constructed once long-term production handling agreements have been agreed with customers. Even liquified natural gas (LNG) plants are often only developed once long-term offtake or LNG sales contracts have been secured.

72 Another approach is to provide for a floating price structure with a price cap and floor. Additionally, PPAs can include provisions that allow for price re-openers if there are significant price or market movements.

73 Alberta Electric System Operator, "Draft Renewable Electricity Support Agreement” (AESO, 2017), online: <aeso.ca/assets/Uploads/Draft-RESA.pdf> [AESO, "Draft RESA"]. 
For many of these types of facilities, proponents are often only willing to take the risk of proceeding with construction if they have been able to secure a long-term agreement with a customer that will (with a high degree of certainty) provide the necessary revenue to justify incurring what are often very significant capital costs. Renewable energy projects are often no different. While a 20-year RESA with the AESO will almost certainly satisfy this requirement, as noted above there is an inherent limit to the capacity that is going to be procured by the government in any jurisdiction, and in Alberta there are projects in development representing far more capacity than is ever likely to be procured pursuant to the Renewable Electricity Program or any other public procurement initiative. As a result, a private PPA may be required in order for a generator to proceed with construction of a renewable energy project.

A potential customer may have similar concerns. In entering into a long-term PPA, a customer is making a commitment to the generator and the associated renewable energy project(s). Inherent in making such a commitment is foregoing other potential opportunities or options to acquire the electricity or products that are the subject matter of the PPA. A customer is unlikely to purchase fundamentally the same good or service twice from two different generators or suppliers (that is, if a customer requires $25 \mathrm{MWh}$ of electricity that customer is unlikely to purchase $25 \mathrm{MWh}$ from one generator and another $25 \mathrm{MWh}$ from another generator), and so entering into a PPA with a generator in all likelihood means that the customer has not also sourced that electricity from another generator or supplier. As a result, if the generator is not ultimately able to complete the construction of the associated renewable energy project(s) and therefore be in a position to deliver the contracted capacity, then the customer will be required to go into the market to make alternative arrangements, which may or may not be available on similarly favourable terms at that time.

As such, from the perspective of both generators and customers, a PPA is really only going to be as good as the potential counterparty. If the financial stability or viability of the counterparty is in doubt, then so too is the ability of that counterparty to meet its obligations under the PPA - whether that is to finish construction of a renewable energy project and deliver electricity or to simply pay for electricity. This is why creditworthiness is such an important issue.

The level of uncertainty about a counterparty's ability to perform is (more or less) a function of creditworthiness. If a generator enters into a PPA with a customer that has an investment-grade credit rating, then the generator will have a high degree of comfort and certainty that the customer will be able to meet its payment obligations. Conversely, if the customer has no credit rating (or other evidence of sufficient financial substance), then the generator is likely to be more concerned. Fortunately, there are a number of mechanisms that can be employed to provide comfort and security when there are doubts or concerns about the creditworthiness of a counterparty (as will often be the case as many potential counterparties will not have robust credit ratings or balance sheets). Financial assurances to provide this security come in many forms, although a guarantee from a parent or affiliate company that has more financial substance or a letter of credit from a recognized financial institution are the most common. Both types of instruments will provide greater certainty that a party will have ready (or at least reasonable) access to capital in the event of a failure to perform by a counterparty. The quantum of such financial assurances will naturally vary 
from case to case and from PPA to PPA, but should be sufficient to cover the costs or losses that a party is likely to incur or be exposed to as a result of such a failure to perform.

\section{Availability and CuRTailment Risk}

Two additional and somewhat related risks associated with renewable energy projects that should be addressed in any PPA are availability and the risk of curtailment. Availability is the risk that a renewable energy project will generate less electricity than is contracted for under a PPA and is inherent in the intermittent nature of renewable energy projects. Curtailment is the risk that not all of the electricity generated by a renewable energy project can be delivered to a customer as a result of constraints on the transmission system (as opposed to as a result of a change in law which is discussed further below). Generally, under a PPA, availability risk will be borne by the customer. The risk that a renewable energy project will produce less electricity due to lower-than-expected wind or solar resources over any period of time is too great for a generator to bear. Having to potentially compensate a customer for any additional costs for the purchase of electricity that the customer may incur as a result of the renewable energy project generating less electricity than anticipated would challenge the economics of most projects.

Further, this risk is easily mitigated by a customer. The customer will already be procuring electricity from the power pool under either a financial PPA or a physical PPA. As such, the quantity of electricity procured by the customer from the power pool will not vary based on the availability of a renewable energy project - all that will vary is the quantity of electricity that needs to be settled as between the generator and the customer under the PPA. As there is no risk (at least in the context of the availability of a renewable energy project) that the customer will not actually receive the quantity of electricity required for its operations, the risk is purely financial - the customer may incur additional costs if the pool price at the time in question is higher than the contract price under the PPA. Conversely, the customer may save if the pool price is less than the contract price. This exposure to fluctuating electricity prices is the same risk that a customer would be exposed to in the absence of a PPA.

The way in which this issue is typically addressed in a PPA is for the financial settlement between generator and customer to only be based on the electricity generated by a renewable energy project that is available to be delivered to the customer. While most PPAs will be expressed in terms of a quantity of electricity generally measured in MWh and based on the generating capacity of the associated renewable energy project, this ultimately serves as the cap or limit on the quantity of electricity that will serve as the basis for the financial settlement over any particular time period. If a renewable energy project generates more electricity than is addressed under a PPA, then the financial settlement will be limited to the contract quantity under the PPA and the generator will be free to sell that additional electricity to the power pool. On the other hand, if the renewable energy project generates less than the contract quantity, then the financial settlement will be based on the actual electricity generated.

Curtailment risk is both similar and different to availability risk. It is similar in that it is (largely) beyond the control of either a generator or a customer - at least in the context of a private PPA that does not involve any governmental or regulatory entities. This can be 
distinguished from the RESAs entered into by generators with the AESO under the Renewable Electricity Program as the AESO is the regulatory entity responsible for the administration of the transmission system in Alberta. However, it differs in that it is not a risk that is inherent to any renewable energy project but rather results from constraints on the transmission system necessary to allow electricity generated by a renewable energy project to reach load connected elsewhere on the transmission system. As the risk may arise through no fault or action of either party to a PPA, and there is little if anything that either party can do to avoid or prevent the risk from materializing (at least at the specific time when a curtailment event occurs), the allocation of this risk between generator and customer is more complicated and will likely be a more contentious issue (relative to availability) during the negotiations relating to a PPA.

It is worth noting that under the RESA, a generator bears the risk of foregone electricity resulting from transmission constraints up to an amount equal to 200 hours multiplied by the contract quantity (expressed in $\mathrm{MWh}$ ) for any year. ${ }^{74}$ This is a relatively significant threshold. Essentially, a renewable energy project will have to be unable to deliver electricity due to transmission constraints for more than 200 hours in any year before the AESO will have any financial responsibility for that foregone electricity. It should also be noted that the AESO is the customer under the RESA, and as noted above the AESO is fundamentally responsible for the development and operation of the transmission system. As such, whether the curtailment risk allocation provisions in the RESA are appropriate for a private PPA will have to be considered by the prospective parties.

Finally, in terms of monitoring and managing this risk during the term of a PPA, a generator (which is likely going to bear some portion of the curtailment risk on the expectation that a customer is not going to agree to bear all of this risk) would be well served to pay close attention to any proposed generation projects (whether renewable energy or conventional) that could have an impact on the capacity for that generator's project to deliver electricity to the grid. A generator will also want to monitor any proposed changes to any applicable transmission or distribution systems for the same purpose. If the generator becomes aware of any proposed generation projects or system changes that could adversely affect the generator's project, then the generator will want to carefully consider any options that may be available through the regulatory processes associated with such generation projects or system changes to attempt to mitigate or eliminate any such adverse effects. While this could ultimately involve an objection to any particular project or system change being permitted to proceed, there may be other less controversial or impactful options available.

\section{E. Change OF LaW}

The final risk we want to address is with respect to a change in law. As could be expected, a change in law could arise in many different contexts and could have many different consequences for the parties. The effects of a change in law could be analogous to the situations addressed in most force majeure provisions - there has been a change in law and as a result one of the parties is prevented or prohibited from performing its obligations under 
a contract, at least for a period of time. While such a consequence could well be material to the parties, as noted these situations are typically addressed through force majeure provisions and would not generally be the subject of a specific change-in-law provision.

The type of change in law that we are principally concerned with addressing is perhaps more subtle - a change in law that results in a change to the economic or financial performance (and attractiveness) of a contract (a PPA) without preventing or prohibiting the performance of the obligations under that contract. A generator is still able to generate and sell electricity and RECs, and a customer is still able to purchase them, but as a result of a change in law the value of the goods bought and sold, or the cost of producing such goods, has materially changed and therefore the benefits accruing to the parties under a PPA has changed. A change in law provision provides an opportunity for the parties to agree in advance how the costs or benefits resulting from such a change are to be shared by the parties, if at all.

Such provisions are particularly relevant given the ongoing development (and revisiting) of policies regarding electricity market structures and renewable energy policies by many governments and the ensuing legislative and regulatory changes to implement such policies. For example, over the past four years in Alberta there have been a number of material changes that have had (and are likely to continue to have) fairly profound effects on the renewable energy industry and that could fall within the purview of a change in law provision:

- $\quad$ On 5 May 2015, the Alberta NDP won a majority government.

- In November 2015, following delivery of the Climate Leadership - Report to Minister, ${ }^{75}$ the Alberta government published its Climate Leadership Plan which focused on five key elements: (1) putting a price on greenhouse gas emissions, (2) ending pollution from coal-generated electricity by 2030, (3) developing more renewable energy, (4) capping oil sands emissions to 100 megatonnes per year, and (5) reducing methane emissions by 45 percent by $2025 .^{76}$

- In June 2016, Alberta enacted the Climate Leadership Act, ${ }^{77}$ imposing a carbon pricing regime on all consumers that started at $\$ 20$ per tonne on 1 January 2017 , increasing to $\$ 30$ per tonne on 1 January 2018 and expected to continue to rise.

- In October 2016, the federal government announced that it would impose a carbon tax of $\$ 10$ per tonne (rising to $\$ 50$ per tonne in 2022) on any province that does not have its own carbon pricing regime.

Andrew Leach et al, "Climate Leadership: Report to Minister" (Edmonton: Government of Alberta, 2015), online: [web.archive.org/web/20190816122722/https://www.alberta.ca/documents/climate/ climate-leadership-report-to-minister.pdf].

76 Government of Alberta, "Climate Leadership Plan" (2019), online: [web.archive.org/web/2019042 9171505/https://www.alberta.ca/climate-leadership-plan.aspx].

77 SA 2016, c C-16.9. 
- In November 2016, the Alberta government announced the introduction of a capacity electricity market, which is expected to have the first capacity obligation periods in 2021 .

- In September 2017, the request for proposals under Round 1 of the Renewable Electricity Program was launched with the winning bidders being announced in December 2017.

- $\quad$ Effective 1 January 2018, the Alberta government replaced the Specified Gas Emitters Regulation $^{78}$ under the Climate Change and Emissions Management Act ${ }^{79}$ (Alberta) with the new Carbon Competitiveness Incentive Regulation. ${ }^{80}$

- In September 2018, the requests for proposals under Rounds 2 and 3 of the Renewable Electricity Program were launched with the winning bidders being announced in December 2018.

- The Alberta Utilities Commission is currently considering whether to allow the AESO to materially change the way in which the AESO tariff applies to distribution-connected generators, including many renewable projects. ${ }^{81}$

While not all of these developments would necessarily fall within the scope of a changein-law provision, many would. It is also worth noting that the list above reflects events in Alberta over slightly less than a four-year period. As discussed above, a PPA will often have a term in excess of ten years and the recently awarded RESAs under the Renewable Electricity Program have a 20 -year term. ${ }^{82}$ Predicting what policy or legislative changes might occur over a 20 -year period is extremely challenging for a mature and stable industry. For an industry as new (and consequently as dynamic and evolving) as the renewable energy industry, and one that is so closely tied to the fierce policy debates and resulting decisions relating to climate change, it is impossible to predict.

Given the election of the UCP government in Alberta as noted above, a change-in-law provision is strongly recommended for PPAs involving Alberta-based renewable energy projects. Even if we assume that the new Alberta UCP government will repeal the Alberta carbon tax, will they be successful in challenging the imposition of the federal carbon tax? What carbon pricing (if any) will replace the Alberta carbon tax? Will the Alberta government proceed with the implementation of a capacity market in Alberta or stay with an energy-only market? The answers to many of these questions (and to many more that we are likely not even thinking to ask at this time) could have a significant impact on the economic performance of a PPA. Whether that impact is going to be positive or negative in all likelihood depends on the perspective of a particular party and is likely a zero-sum game - any change that serves to benefit one party to a PPA likely comes at the expense of the

See Proceeding 23757 (23 July 2018), 23757-A001, online: AUC <www.auc.ab.ca/regulatory_ documents/ProceedingDocuments/2018/23757.pdf>.

AESO, "Draft RESA," supra note 73, art 15.1. 
other party. This is why a change-in-law provision should be carefully considered. While there is no right answer in terms of what such a provision should encompass or how future changes should necessarily be addressed (see Article 12 of the RESA as one example of what types of changes in law are covered and how the consequences of such changes on the parties are addressed), ${ }^{83}$ the parties would be well served to turn their minds to likely eventualities or possibilities to try to reach an equitable agreement as to how to deal with any such change as between themselves. A failure to do so will often result in a winner and a loser under a PPA as a result of the change, and this will put a great deal of pressure on the commercial relationship between the parties and the contract. If one party is no longer receiving the expected benefit under a PPA, and the other party is receiving more than expected, then the likelihood of a dispute between the parties increases significantly.

\section{CONCLUSION}

While there has been significant growth in the use of renewable PPAs in the US, we have not seen a corresponding growth in Canada. This lack of growth persists despite very favourable market and regulatory regimes for private PPAs at least in Alberta. In reviewing the regulatory structures that facilitate PPAs and examining some of the risks that generators and customers will want to consider under any PPA, we hope that potential project developers and customers will come away with a better understanding of what a private PPA might entail and the benefits that could result from (and the risks that could be mitigated by) such an agreement. Ideally, we have helped to demystify the notion of a private PPA, and hopefully, this will facilitate transactions and the growth of this industry. 